\title{
Kinetic, Equilibrium and Phytotoxicity Studies for Dyes Removal by Low Cost Natural Activated Plant-Based Carbon
}

\section{Emilia Neag, ${ }^{1, *}$ Ana Moldovan,, ${ }^{1,2}$ Vanda Băbălău-Fuss, ${ }^{1,3}$ Anamaria Török, ${ }^{1}$ Oana Cadar ${ }^{1}$ and Cecilia Roman ${ }^{1}$}

${ }^{1}$ INCDO-INOE 2000, Research Institute for Analytical Instrumentation, 67 Donath Street, 400293 Cluj-Napoca, Romania

2 Technical University, Faculty of Materials and Environmental Engineering, 103-105 Muncii Boulevard, 400641 Cluj-Napoca, Romania

${ }^{3}$ Faculty of Science and Technology Food, University of Agricultural Sciences and Veterinary Medicine, 3-5 Manastur Street, 400372 Cluj-Napoca, Romania

*Corresponding author: E-mail: emilia.neag@icia.ro Tel: +40264 420590, Fax: +40264420667

Received: 12-09-2018

\begin{abstract}
The capacity of commercial natural activated plant-based carbon (CNAC) to remove different dyes such as methylene blue (MB), eosin yellow (EY) and rhodamine B (RB) was studied. Also, the germination index (GI) was calculated in order to examine the dyes toxicity on various plant seeds by recording and measuring the number of germinated seeds and root length, respectively. Generally, the results showed that high concentrations of dyes inhibit the seed germination by changing their colors and affecting their growth. The inhibition of corn seeds germination in RB was very low in the studied range of concentration. The adsorption behavior of dyes onto CNAC surface was investigated through isotherm and kinetics modeling. The parameters predicted from the Langmuir and Freundlich isotherms suggested a favorable adsorption of the considered dyes onto CNAC surface. The kinetic studies showed that the adsorption followed pseudo-second-order kinetic model for MB and RB removal, but was not adequate for EY removal.
\end{abstract}

Keywords: Activated carbon; dyes removal; isotherm models; kinetic models

\section{Introduction}

The water pollution caused by textile industries discharges has a negative impact on environment and human health due to their synthetic origin and complex molecular structure, which makes them more stable and difficult to be biodegraded. ${ }^{1,2}$

Dyes, such as methylene blue (MB), eosin yellow (EY) and rhodamine $B(\mathrm{RB})$ are used in various areas, including textile, plastics, rubber, leather, cosmetics, food and paper industries, chemistry, biology and medical science. ${ }^{1,3-6}$ Thus, a suitable treatment method of industrial wastewaters before being released into the water is desirable. ${ }^{1}$ Moreover, the phytotoxicity effect of the textile dyes on environment can be evaluated using simple, rapid, reliable and reproducible techniques such as seed germination and root shoot ratio tests. ${ }^{7}$
Many cheap, easily available low cost adsorbents, such as rice hull ash, sawdust, pine needle and cone powder, soya bean waste, prawn and coconut shell activated carbon, mango seed kernel powder, Ficus carica bast activated carbon and walnut carbon have been used as feedstock for the production of activated carbon for textile dye effluents treatment. ${ }^{4,6,8-11}$

Numerous techniques including physical, chemical and biological treatments have been undertaken for dyes removal from wastewater. ${ }^{12}$ Among other methods, adsorption has gained attention due to its efficiency, low energy consumption and cost, high selectivity, and easy operation. ${ }^{1,13}$

In a previous work, we have successfully identified the optimum adsorption conditions for MB removal on commercial natural activated plant-based carbon 
(CNAC) using Taguchi experimental design, a simple and fast method. ${ }^{14}$ In this work, an important progress was achieved through the application of several models in order to obtain more information related to the adsorption process involved in dyes removal such as $\mathrm{MB}, \mathrm{EY}$ and $\mathrm{RB}$.

The objectives of this study were: (1) to investigate the capacity of CNAC for MB, EY and RB removal from synthetic aqueous solution; (2) to evaluate the potential application of CNAC for dyes removal; (3) to obtain more information related to the adsorption process through equilibrium and kinetic studies, and (4) to determine the phytotoxic effect of $\mathrm{MB}, \mathrm{EY}$ and $\mathrm{RB}$ on different seeds growth (mustard, chickpea and corn).

\section{Materials and Methods}

\section{1. Materials}

The CNAC was purchased from Romanian market and ground using a mortar and pestle and then sieved through a $0.5 \mathrm{~mm}$ sieve. Its physical characteristics, including determination of $\mathrm{pH}$, point zero charge $\left(\mathrm{pH}_{\mathrm{pzc}}\right)$, apparent density, volatile matter, moisture and ash content, were presented in a previous study. ${ }^{14}$

\section{2. Chemicals}

All used chemicals (Merck, Germany) were of analytical purity and used as received, without any further purification. $\mathrm{MB}, \mathrm{EY}$ and $\mathrm{RB}$ were purchased in powder form. The chemical structures of the considered dyes are presented in Fig. 1. ${ }^{15,6,5}$ The stock solutions were prepared by dissolving $1.00 \mathrm{~g}$ dye in $1 \mathrm{~L}$ of double distilled water. The calibration standards $(2-10 \mathrm{mg} / \mathrm{L})$ and a series of solutions (100-300 mg/L) were prepared by appropriate dilution of stock dye solutions of $\mathrm{MB}, \mathrm{EY}$ and RB.
After $300 \mathrm{~min}$, the dye solutions were separated from the CNAC by centrifugation at $4500 \mathrm{rpm}$ for $5 \mathrm{~min}$. The concentration of $\mathrm{MB}, \mathrm{EY}$ and $\mathrm{RB}$ in solution was determined at previously established time intervals using a Lambda 25 Perkin-Elmer UV/VIS spectrophotometer at $665 \mathrm{~nm}, 515 \mathrm{~nm}$ and $554 \mathrm{~nm}$, respectively.

The amount retained of $\mathrm{MB}, \mathrm{EY}$ and $\mathrm{RB}$ in the adsorbent phase was calculated using equation (1), while dyes removal efficiency was calculated by equation (2):

$$
\begin{aligned}
& q_{e}=\frac{\left(C_{0}-C_{e}\right)}{m} \cdot \frac{V}{1000} \\
& E(\%)=\frac{\left(C_{0}-C_{e}\right)}{C_{0}} \cdot 100
\end{aligned}
$$

where $q_{e}$ is the amount of dye adsorbed per gram of adsorbent, at equilibrium $(\mathrm{mg} / \mathrm{g}), V$ is the volume $(\mathrm{mL}), m$ is the weight of the adsorbent $(\mathrm{g}), E$ is the removal efficiency (\%), $C_{o}$ and $C_{e}$ are the initial and equilibrium concentrations of $\mathrm{MB}, \mathrm{EY}$ and $\mathrm{RB}$ solutions $(\mathrm{mg} / \mathrm{L}) .{ }^{16}$

\section{4. Phytotoxicity Study}

The phytotoxicity effect of MB, EY and RB dyes was studied on corn, chickpea and mustard seeds. 10 seeds were placed in Petri-dishes and $5 \mathrm{~mL}$ dye solution of different initial concentrations (100, 200 and $300 \mathrm{mg} / \mathrm{L})$ were added. The samples were kept in a dark chamber for 5 days at $25{ }^{\circ} \mathrm{C}$. The number of seeds and root growth were recorded every day, up to 5 days. The germination index $(G I)$ was calculated using the equations 3,4 and $5:{ }^{7}$

$$
\begin{aligned}
& G I=\frac{R S G \times R G}{100} \\
& R S G=\frac{N_{d}}{N_{c}} \times 100
\end{aligned}
$$<smiles></smiles>

a)<smiles></smiles>

b)<smiles>[N+]O[C@H](O[Na])c1ccccc1-c1c2cc(Br)c(=O)c(Br)c-2oc2c(Br)c(O[N+]([O-])([O-])O)c(Br)cc12</smiles>

Fig. 1. Chemical structures of dyes: (a) MB; (b) RB; (c) EY.

\section{3. Adsorption}

The experiments were performed in batch conditions, contacting different quantities of CNAC (0.5-1.5 g) with $50 \mathrm{~mL}$ dye aqueous solutions at different initial concentrations (100-300 mg/L), room temperature (25 \pm 2 ${ }^{\circ} \mathrm{C}$ ) and $75 \mathrm{rpm}$ for $300 \mathrm{~min}$.

$$
R G=\frac{M_{d}}{M_{c}} \times 100
$$

where $R S G$ is the relative seed germination (\%), $R G$ is the root growth (\%), $N_{d}$ is the number of seeds germinated in dye solution, $N_{c}$ is the number of seeds germinated in con- 
trol sample, $M_{d}$ is the mean root length in dye solution $(\mathrm{cm}), M_{c}$ is the mean root length in control sample $\left.\mathrm{cm}\right){ }^{7}$

\section{Experimental Data Modeling}

\section{1. Equilibrium Modeling}

In order to investigate the MB, EY and RB removal, the experimental results were analyzed by the Langmuir, Freundlich and Dubinin-Radushkevich isotherms.

The Langmuir isotherm can be used to describe a monolayer adsorption onto a surface ${ }^{17}$ and its linear form is as follow:

$$
\frac{1}{q_{e}}=\frac{1}{q_{\max } K_{L} C_{e}}+\frac{1}{q_{\max }}
$$

where $K_{L}$ is the Langmuir adsorption constant $(\mathrm{L} / \mathrm{mg})$ and $q_{\max }$ is the maximum amount of dye adsorbed per gram of adsorbent $(\mathrm{mg} / \mathrm{g}){ }^{1,18}$

The Langmuir parameters, $q_{\max }$ and $K_{L}$, are calculated from the slope and intercept of the plot $1 / q_{e}$ vs. $1 / C_{e}$. The Langmuir isotherm can be expressed by a dimensionless constant known as the separation factor or equilibrium parameter $\left(R_{L}\right):^{19}$

$$
R_{L}=\frac{1}{1+K_{L} C_{0}}
$$

where $C_{0}$ is the initial dye concentration $(\mathrm{mg} / \mathrm{L})$.

The $R_{L}$ value indicates the adsorption nature and may be unfavorable $\left(R_{L}>1\right)$, linear $\left(R_{L}=1\right)$, favorable $(0<$ $\left.R_{L}<1\right)$ or irreversible $\left(R_{L}=0\right){ }^{20}$

The Freundlich isotherm is applicable to describe heterogeneous systems. ${ }^{21}$ Its linear form is given as follows:

$$
\log q_{\theta}=\log K_{F}+\frac{1}{n} \log C_{e}
$$

where $K_{F}$ is the adsorption capacity $(\mathrm{L} / \mathrm{g})$ and $1 / n$ is the adsorption intensity. ${ }^{1,20}$

The Freundlich parameters, $K_{F}$ and $n$, are obtained from the $\log q_{e} v s . \log C_{e}$ linear plot. The $\mathrm{n}$ value between 1 $<n<10$ indicates a favorable adsorption. ${ }^{22}$

The Dubinin-Radushkevich model is applied to express the nature of adsorption process (physical or chemi$\mathrm{cal}^{23,24}$ and the related equations are given below:

$$
\begin{aligned}
& \ln q_{e}=\ln q_{\max }-\beta \varepsilon^{2} \\
& \varepsilon=R T \ln \left(1+\frac{1}{C_{e}}\right) \\
& E_{L}=\frac{1}{\sqrt{-2 \beta}}
\end{aligned}
$$

where $\beta$ is the Dubinin-Radushkevich constant $\left(\mathrm{mol}^{2} / \mathrm{kJ}{ }^{2}\right)$, $R$ is the gas constant $(8.314 \mathrm{~J} / \mathrm{mol} \mathrm{K}), T$ is the absolute temperature $(\mathrm{K}), \varepsilon$ is the Polanyi potential and $E_{L}$ is the mean adsorption energy $(\mathrm{kJ} / \mathrm{mol}){ }^{20}$

Dubinin-Radushkevich parameters, $q_{\max }$ and $\beta$, are obtained by plotting $\ln q_{e} v s$. $\varepsilon^{2}$. If $E_{L}<8 \mathrm{~kJ} / \mathrm{mol}$, the adsorption process is physisorption, while if $E_{L}$ ranges between 8 and $16 \mathrm{~kJ} / \mathrm{mol}$, the process is chemisorption. ${ }^{24}$

\section{2. Kinetics Modeling}

Four kinetics models (pseudo-first-order, pseudo-second-order, intraparticle diffusion and external diffusion) were applied for the considered dyes removal in order to fit the experimental data.

The linearized form of pseudo-first-order equation is expressed as follows: ${ }^{25}$

$$
\ln \left(q_{e}-q_{t}\right)=\ln q_{e}-k_{1} 1
$$

where $q_{t}$ is the amount of adsorbed at time $t(\mathrm{mg} / \mathrm{g}), k_{1}$ first-order rate constant $(1 / \mathrm{min}){ }^{25}$

The pseudo-first-order parameters $q_{e}$ and $k_{1}$ are calculated from the slope and intercept of the plot $\ln \left(q_{e}-q_{t}\right)$ vs. $t^{25}$

The linearized form of pseudo-second-order equation is expressed as: ${ }^{26}$

$$
\frac{t}{q_{t}}=\frac{1}{k_{2} q_{\varepsilon}{ }^{2}}+\frac{1}{q_{\varepsilon}} t
$$

where $k_{2}$ is the pseudo-second-order rate constant $(\mathrm{g} / \mathrm{mg}$. $\min ) .{ }^{26}$

The pseudo-second-order parameters $q_{e}$ and $k_{2}$ are obtained from the slope and intercept of the plot of $t / q_{t} v s$. $t^{26}$

The intraparticle diffusion model is applied to investigate if the diffusion of the solute molecules into the pores is the rate determining step ${ }^{27}$ and is given as:

$$
q_{t}=k_{i p} \cdot t^{1 / 2}+b
$$

where $k_{i p}$ is the intraparticle diffusion rate constant $(\mathrm{mg} /$ $\left.\mathrm{g} \cdot \mathrm{min}^{1 / 2}\right), b$ is the intraparticle diffusion constant $(\mathrm{mg} / \mathrm{g})$ and $t$ is time $(\mathrm{min})$.

The $b$ value provides information about the thickness of boundary layer and external mass transfer resistance. $^{11}$

If a plot of $q_{t} v s . t^{1 / 2}$ give a straight line, the adsorption process is controlled only by intraparticle diffusion and the rate constant $k_{i p}$ is determined from the slope of the regression line. ${ }^{11}$

The linearized form of Elovich model is used to describe the chemisorption kinetics and its equation is given below: ${ }^{3}$ 


$$
q_{t}=\frac{1}{C} \ln \alpha C+\frac{1}{C} \ln t
$$

where $\alpha$ is the initial rate $(\mathrm{mg} / \mathrm{g} \cdot \mathrm{min})$ and $C$ is the activation energy for chemisorption $(\mathrm{g} / \mathrm{mg}) .^{3}$

The Elovich parameters $(\alpha, \beta)$ are obtained from the slope and intercept of the plot $q_{t} v s . \ln t^{3}$

Bangham model is used to identify if the intraparticle diffusion is the rate-controlling step and is given as follows: ${ }^{3}$

$$
\log \left(\log \frac{C_{0}}{C_{0}-q_{t} m}\right)=\log \left(\frac{K_{0} m}{2.303 V}\right)+p \log t
$$

where $p$ and $K_{0}$ are the Bangham constants. ${ }^{3}$

The kinetic parameters are obtained from the slope and the intercept of the plot $\log \left(\log C_{o} /\left(C_{o}-q_{t} m\right) v s . \log t^{3}\right.$

Dumwald-Wagner model, which is an intraparticle diffusion model, is applied to determine the rate-controlling step and is given below: ${ }^{28}$

$$
\log \left[1-\left(\frac{q_{t}}{q_{e}}\right)^{2}\right]=-\frac{k}{2.303} t
$$

where $k$ is the rate constant of adsorption. ${ }^{28}$

The kinetic parameters are obtained from the slope and the intercept of the plot $\log \left[1-\left(q_{t} / q_{e}\right)^{2}\right] v$ s. $t^{28}$

\section{Results and Discussion}

\subsection{Effect of Adsorbent Dose}

The effect of adsorbent dose for MB, EY and RB adsorption onto CNAC, was studied by taking different quantities of CNAC (0.5-1.5 g) with $50 \mathrm{~mL}$ dye solutions of $100 \mathrm{mg} / \mathrm{L}$ at room temperature $\left(25 \pm 2{ }^{\circ} \mathrm{C}\right)$ for $300 \mathrm{~min}$.

The results obtained for $\mathrm{MB}, \mathrm{EY}$ and $\mathrm{RB}$ adsorption onto CNAC surface are presented in Fig. 2. The removal efficiency slowly increased as the adsorbent dosage increase. An increasing trend was observed for MB (46-78 $\%)$, EY (51-70 \%) and RB (52-60 \%) removal by varying the adsorbent doses due to the availability of a larger number of active sites for dyes species in solution. ${ }^{29}$

After a certain dosage, the increase in removal efficiency is insignificant due to the fast superficial adsorption onto the adsorbent surface. ${ }^{30}$ Consequently, with increasing the adsorbent dose, the amount of dye adsorbed per unit mass of adsorbent at equilibrium is reduced ${ }^{30}$, thus smaller $q_{e}$ values were obtained by increasing the adsorbent dose of CNAC. The maximum amounts of adsorbed $\mathrm{MB}, \mathrm{EY}$ and RB on the surface of $0.5 \mathrm{~g}$ CNAC were 4.64 , 5.65 and $4.37 \mathrm{mg} / \mathrm{g}$, respectively.

Huang et al. 2011 studied the removal of anionic dye EY from aqueous solution using ethylenediamine modified chitosan. They reported that larger particle size lead to lower amount of dye adsorbed, due to the higher surface
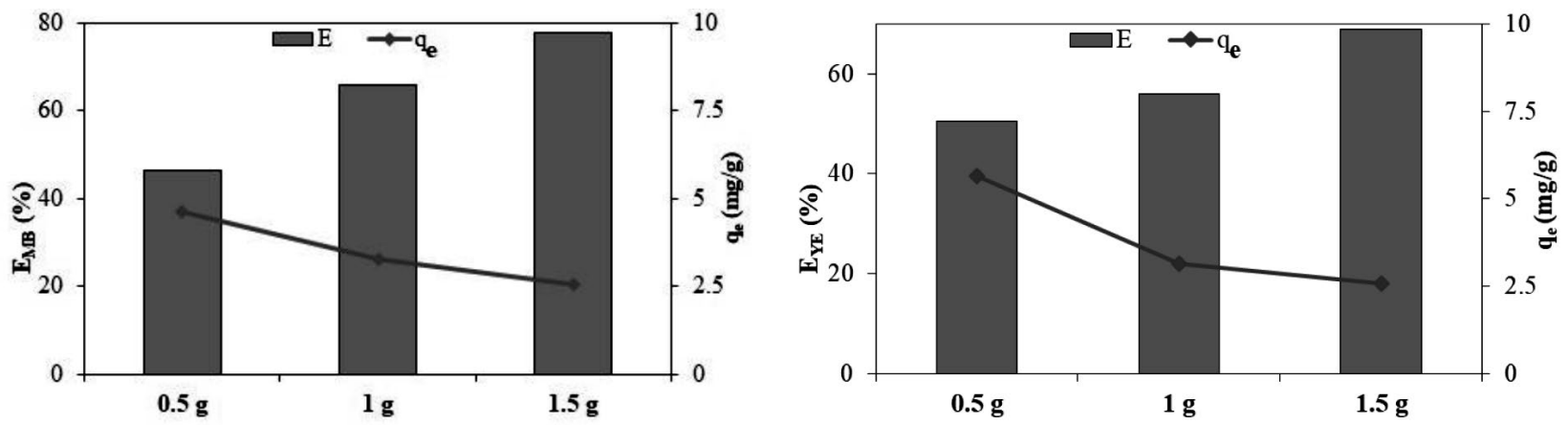

a)

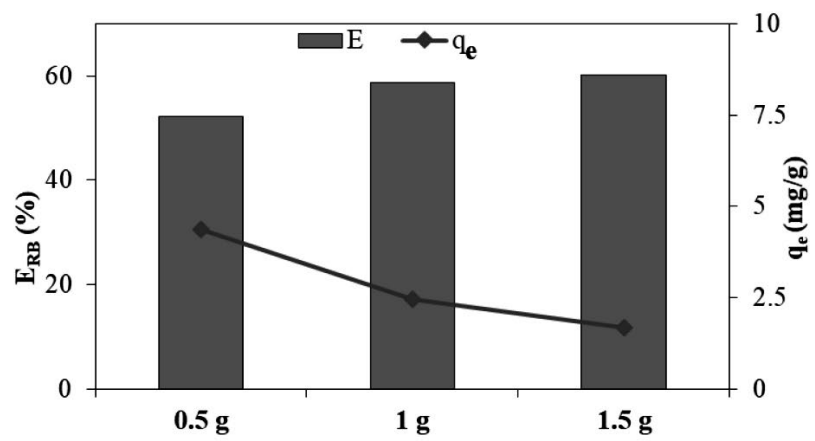

c)

Fig. 2. Removal efficiency of MB (a), EY (b) and RB (c) adsorption onto CNAC surface at different adsorbent doses $\left(C_{o}=100 \mathrm{mg} / \mathrm{L}, \mathrm{m}=0.5-1.5 \mathrm{~g}\right.$, particle size $=<0.5 \mathrm{~mm}$, stirring rate $=75 \mathrm{rpm}, V=50 \mathrm{~mL}$; time $=300 \mathrm{~min}$ ) 
area of smaller particles compared to larger particles of the same mass. ${ }^{31}$

\section{2. Effect of Initial Dye Concentration}

The experiments were carried out using a fixed adsorbent dose ( $1.5 \mathrm{~g})$ and stirring rate $(75 \mathrm{rpm})$, but varying the initial dyes concentration (100-300 mg/L) (Fig. 3).

The dyes adsorption was rapid in the initial stages (100 min), increases gradually and finally becomes almost constant after reaching equilibrium. The rapid uptake of Astrazone Blue adsorption onto dried biomass of Baker's yeast suggested that the removal process could be ionic in nature due to the fact that the negatively charged organic

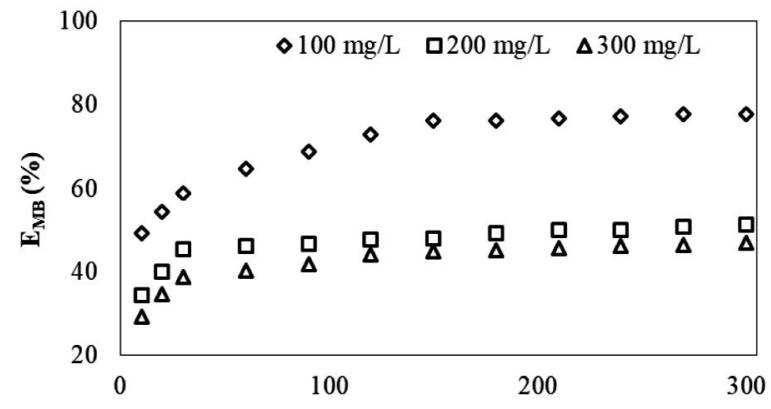

a) functional groups from the adsorbent surface may speed up the adsorption of dyes molecule. ${ }^{32}$

The removal efficiency of $\mathrm{MB}, \mathrm{EY}$ and $\mathrm{RB}$ decreases with the increase of initial dye concentration. By increasing the initial dye concentration from 100 to $300 \mathrm{mg} / \mathrm{L}$, the dye amount in the adsorbent phase at equilibrium $\left(q_{e}\right)$ increased from 2.59 to $4.68 \mathrm{mg} / \mathrm{g}$ for $\mathrm{MB}$, from 2.56 to $3.36 \mathrm{mg} / \mathrm{g}$ for $\mathrm{EY}$, and from 1.65 to $4.34 \mathrm{mg} / \mathrm{g}$ for RB removal, respectively and the higher mass transfer is driving force of the process. ${ }^{30}$

\section{3. Isotherm Modeling}

The equilibrium data for $\mathrm{RB}, \mathrm{MB}$ and $\mathrm{EY}$ removal onto CNAC surface were modeled using the Lan-

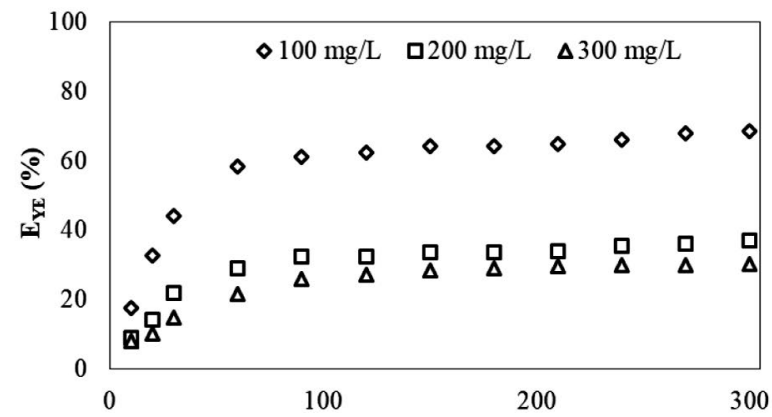

b)

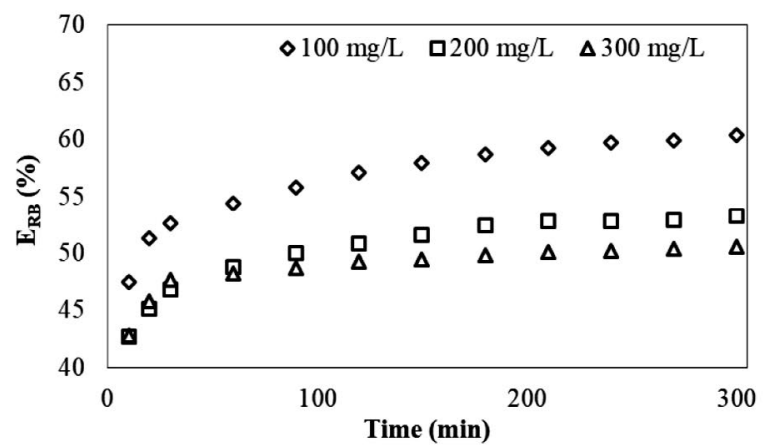

c)

Fig. 3. Removal efficiency of MB (a), EY (b) and RB (c) adsorption on CNAC surface at different initial concentrations in time $\left(C_{o}=100-300 \mathrm{mg} / \mathrm{L}\right.$, $m=1.5 \mathrm{~g}$, particle size $=<0.5 \mathrm{~mm}$, stirring rate $=75 \mathrm{rpm}, V=50 \mathrm{~mL}$, time $=300 \mathrm{~min}$ )

Table 1. Langmuir, Freundlich and Dubinin-Radushkevich isotherm parameters for dyes removal on CNAC surface.

\begin{tabular}{llccc}
\hline Isotherm model & Parameters & MB & EY & RB \\
\hline Langmuir & $q_{\max /}(\mathrm{mg} / \mathrm{g})$ & 4.54 & 3.09 & 9.45 \\
& $K_{L} /(\mathrm{L} / \mathrm{mg})$ & 0.06 & 0.13 & 0.006 \\
& $R^{2}$ & 0.860 & 0.407 & 0.999 \\
\hline Freundlich & $n$ & 3.64 & 8.43 & 1.41 \\
& $K_{F} /(\mathrm{L} / \mathrm{mg})$ & 1.08 & 1.63 & 7.14 \\
& $\mathrm{R}^{2}$ & 0.901 & 0.569 & 0.999 \\
\hline Dubinin-Radushkevich & $\left.\beta /\left(\mathrm{mol}^{2} / \mathrm{kJ}\right)^{2}\right)$ & $3 \times 10^{-9}$ & $1 \times 10^{-9}$ & $7 \times 10^{-9}$ \\
& $E_{L} /(\mathrm{kJ} / \mathrm{mol})$ & 12.91 & 22.36 & 8.45 \\
& $R^{2}$ & 0.887 & 0.545 & 1 \\
\hline
\end{tabular}

Neag et al.: Kinetic, Equilibrium and Phytotoxicity Studies for ... 
gmuir, Freundlich and Dubinin-Radushkevich isotherms.

The Langmuir parameters, $q_{\max }$ and $K_{L}$, for the considered dyes are presented in Table 1 . The calculated $R_{L}$ values for the removal of $\mathrm{MB}(0.05), \mathrm{EY}(0.02)$ and $\mathrm{RB}$ (0.4) indicated a favorable adsorption. Similar results were reported by Hameed et al., 2017 for the adsorption of chromotrope dye onto activated carbons obtained from the seeds of various plants. ${ }^{12}$

The Freundlich parameters, $K_{F}$ and $n$ are given in Table 1 . The $n$ values obtained for $\mathrm{MB}, \mathrm{EY}$ and $\mathrm{RB}$ removal were found to be greater than 1 , indicating a favorable adsorption of dyes onto CNAC.

The correlation coefficient $\left(R^{2}\right)$ indicated that Freundlich model fitted better the experimental results for $\mathrm{MB}$ and $\mathrm{RB}$ removal suggesting a heterogeneous coverage of dye molecules on the CNAC surface. In contrast, for EY removal, the $R^{2}$ values were low, suggesting that the monolayer and the heterogeneous coverage of dye molecules on the CNAC surface didn't take place.

The Dubinin-Radushkevich parameters, $q_{\max }$ and $\beta$, are given in Table 1 . The mean free energy value indicated a chemically process involved for $\mathrm{MB}$ and $\mathrm{RB}$ removal.

\section{4. Kinetics Modeling}

In order to describe the adsorption kinetics the pseudo-first-, pseudo-second-order, intraparticle, Elovich, Bangham and Dumwald-Wagner kinetics models were used.

The pseudo-first-order equation parameters are presented in Table 2 . The calculated $q_{e}$ values are different from the experimental values for the considered dyes. Also, the obtained $R^{2}$ values are low for MB and RB removal suggesting that pseudo-first-order equation cannot be used to describe the kinetics of $\mathrm{MB}, \mathrm{EY}$ and $\mathrm{RB}$.

The pseudo-second-order parameters are listed in Table 2. Based on the obtained results, some differences are observed between the calculated and experimental $q_{e}$ values for EY removal. On the contrary, the values of these parameters for $\mathrm{MB}$ and $\mathrm{RB}$ removal are similar.

The values of $R^{2}$ are higher than those obtained from the pseudo-first-order model suggesting that the pseudo-second-order kinetics model is adequate to describe the $\mathrm{MB}$ and $\mathrm{RB}$ removal as chemisorption process. However, the process involved in EY removal cannot be described by the pseudo-second-order kinetic model. Similar results were reported for the adsorption kinetics of $\mathrm{RB}$ and $\mathrm{MB}$ onto waste of seeds of Aleurites Moluccanav, a low cost adsorbent. ${ }^{1}$

Elovich kinetics model was employed to confirm the results obtained from Dubinin-Radushkevich isotherm and pseudo-second-order kinetic model. The $R^{2}$ values indicated that experimental data fitted well on Elovich equation (Table 2). The obtained results are in agreement with the results obtained from Dubinin-Radushkevich isotherm and pseudo-second-order kinetic model in case of $\mathrm{MB}$ and $\mathrm{RB}$.

The intraparticle diffusion model was used to investigate the mechanism of mass transport and to determine the rate controlling step during dyes adsorption on the surface of adsorbent. ${ }^{3}$ The obtained values (Table 3 ) indicated that intraparticle diffusion is not the only rate determining step for the considered dyes because the intercept values are higher than 0 and another model is required to follow the experimental data.

Further, Bangham and Dumwald-Wagner kinetic models were taken into consideration. The kinetic parameters obtained for Bangham and Dumwald-Wagner models are presented in Table 3. The experimental data do not give a good fit to the Bangham and DumwaldWagner model (low $R^{2}$ obtained) for the considered dyes. The results obtained using these kinetic models confirmed that intraparticle diffusion is not the rate-controlling step.

Table 2. Pseudo-first-order, pseudo-second-order reaction and Elovich kinetics constants for dyes removal on CNAC surface at different initial concentrations.

\begin{tabular}{|c|c|c|c|c|c|c|c|c|c|c|}
\hline \multirow{2}{*}{$\frac{\text { Kinetics Model }}{\text { Pseudo-first-order }}$} & \multirow{2}{*}{$\frac{\text { Parameters }}{C_{o} /(\mathrm{mg} / \mathrm{L})}$} & \multicolumn{3}{|c|}{ MB } & \multicolumn{3}{|c|}{ EY } & \multicolumn{3}{|c|}{ RB } \\
\hline & & 100 & 200 & 300 & 100 & 200 & 300 & 100 & 200 & 300 \\
\hline & $k_{1} \cdot 10^{-2} /(1 / \mathrm{min})$ & 2.3 & 1.2 & 1.3 & 1.4 & 1.2 & 1.7 & 1.3 & 0.8 & 1.4 \\
\hline & $q_{e(\text { calc })} /(\mathrm{mg} / \mathrm{g})$ & 1.98 & 1.13 & 1.96 & 1.64 & 1.73 & 2.83 & 2.15 & 1.24 & 1.28 \\
\hline & $\mathrm{R}^{2}$ & 0.888 & 0.868 & 0.939 & 0.915 & 0.926 & 0.991 & 0.860 & 0.735 & 0.813 \\
\hline \multirow{5}{*}{$\begin{array}{l}\text { Pseudo-second- } \\
\text { order }\end{array}$} & $C_{o} /(\mathrm{mg} / \mathrm{L})$ & 100 & 200 & 300 & 100 & 200 & 300 & 100 & 200 & 300 \\
\hline & $k_{1} \cdot 10^{-2} /(\mathrm{g} / \mathrm{mg} \min )$ & 3.1 & 3.9 & 2.2 & 1.2 & 1.0 & 0.7 & 9.4 & 5.1 & 7.7 \\
\hline & $q_{e(\text { calc })} /(\mathrm{mg} / \mathrm{g})$ & 2.69 & 3.45 & 4.78 & 2.82 & 2.85 & 3.81 & 1.67 & 3.01 & 4.36 \\
\hline & & 0.998 & 0.999 & 0.999 & 0.991 & 0.992 & 0.997 & 0.998 & 0.998 & 0.999 \\
\hline & $q_{e(\exp )} /(\mathrm{mg} / \mathrm{g})$ & 2.59 & 3.42 & 4.68 & 2.56 & 2.60 & 3.36 & 1.65 & 3.03 & 4.34 \\
\hline \multirow[t]{4}{*}{ Elovich } & $C_{o} /(\mathrm{mg} / \mathrm{L})$ & 100 & 200 & 300 & 100 & 200 & 300 & 100 & 200 & 300 \\
\hline & $\alpha$ & 0.65 & 1.65 & 1.22 & 1.15 & 0.59 & 0.04 & 2.66 & 2.30 & 3.20 \\
\hline & $\theta$ & 0.30 & 0.28 & 0.48 & 0.56 & 0.58 & 0.80 & 0.07 & 0.17 & 0.13 \\
\hline & $R^{2}$ & 0.981 & 0.910 & 0.967 & 0.912 & 0.925 & 0.968 & 0.907 & 0.947 & 0.966 \\
\hline
\end{tabular}


Table 3. Intraparticle diffusion, Bangham and Dumwald-Wagner rate coefficients for dyes removal on CNAC surface at different initial concentrations

\begin{tabular}{lllllllcccc}
\hline Kinetics Model & Parameters & & MB & & & EY & & RB \\
\hline Intraparticle & $C_{o} /(\mathrm{mg} / \mathrm{L})$ & 100 & 200 & 300 & 100 & 200 & 300 & 100 & 200 & 300 \\
diffusion & $k_{i p}\left(\mathrm{mg} / \mathrm{g} \mathrm{min}^{1 / 2}\right)$ & 0.067 & 0.061 & 0.106 & 0.119 & 0.125 & 0.175 & 0.017 & 0.038 & 0.030 \\
& $b$ & 1.565 & 2.438 & 3.039 & 0.762 & 0.643 & 0.704 & 1.354 & 2.349 & 3.852 \\
& $R^{2}$ & 0.926 & 0.800 & 0.868 & 0.753 & 0.808 & 0.879 & 0.941 & 0.911 & 0.913 \\
\hline Bangham & $C_{o} /(\mathrm{mg} / \mathrm{L})$ & 100 & 200 & 300 & 100 & 200 & 300 & 100 & 200 & 300 \\
& $K_{0}$ & 0.63 & 0.64 & 0.65 & 0.69 & 0.71 & 0.72 & 0.631 & 0.639 & 0.632 \\
& $p^{2}(\mathrm{dm} / \mathrm{g})$ & 0.14 & 0.10 & 0.12 & 0.41 & 0.40 & 0.40 & 0.05 & 0.06 & 0.03 \\
& $\mathrm{R}^{2}$ & 0.981 & 0.883 & 0.943 & 0.786 & 0.859 & 0.936 & 0.859 & 0.946 & 0.963 \\
\hline \multirow{2}{*}{ Dumwald-Wagner } & $C_{o} /(\mathrm{mg} / \mathrm{L})$ & 100 & 200 & 300 & 100 & 200 & 300 & 100 & 200 & 300 \\
& $k /(1 / \mathrm{min})$ & 0.023 & 0.010 & 0.012 & 0.012 & 0.009 & 0.015 & 0.011 & 0.004 & 0.011 \\
& $C$ & 1.024 & 0.820 & 0.617 & 0.076 & 0.063 & 0.059 & 0.433 & 0.47 & 0.06 \\
& $R^{2}$ & 0.858 & 0.945 & 0.984 & 0.919 & 0.943 & 0.994 & 0.935 & 0.937 & 0.944 \\
\hline
\end{tabular}

\section{5. The Effect of Dyes on Seeds Growth}

The effect of $\mathrm{MB}, \mathrm{EY}$ and $\mathrm{RB}$ on germination of chickpea, mustard and corn seeds was studied. Different initial dye concentrations in the range of $100-300 \mathrm{mg} / \mathrm{L}$ were used along with control samples. After 5 days, the number of seeds and root growth were recorded. The GI decreases with an increase of dyes concentration from 100 to $300 \mathrm{mg} / \mathrm{L}$ (Fig. 4).

At $300 \mathrm{mg} / \mathrm{L}$ initial concentration, in case of $\mathrm{MB}$ for corn and chickpea seeds, the GI was around 63 and $65 \%$, respectively while for mustard seed only $53 \%$ suggesting that the inhibition increases with an increase of MB concentration. The same pattern was observed for EY where the GI was lower than in case of MB for mustard and corn seeds.

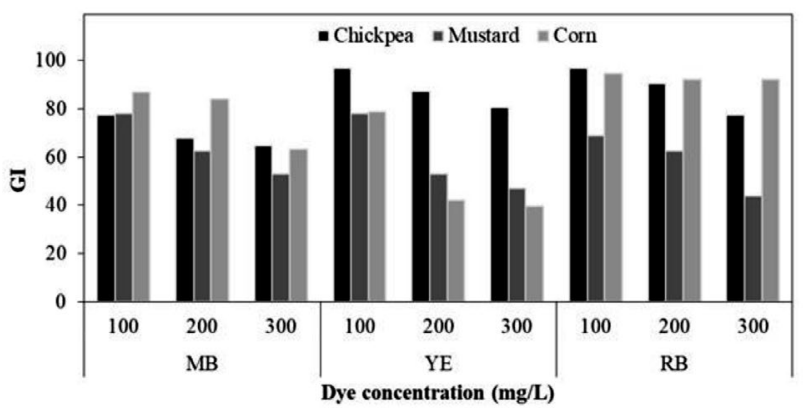

Fig. 4. Germination indices for chickpea, mustard and corn plant seeds after 5 days.

In case of RB, the GI for corn seeds were very high in the studied range of concentration (92-95\%), suggesting that the inhibition didn't take place. For mustard seed, the GI values were much lower ( $44 \%$ at $300 \mathrm{mg} / \mathrm{L} \mathrm{RB}$ ), indicating that inhibition was high.

Generally, the seed roots were long in the control sample (chickpea $3.1 \mathrm{~cm}$, mustard $3.2 \mathrm{~cm}$ and corn 3.8 $\mathrm{cm}$ ), while in the dye solution were smaller and became colorful. Rápó et al. also reported that the inhibition increases with an increase of dye concentration for seedling growth for lettuce and mustard seeds. ${ }^{33}$

\section{Conclusions}

The adsorption behaviour of MB, YE and RB removal onto CNAC surface was examined by studying the effect of adsorbent dosage and initial dyes concentration. The adsorption process of $\mathrm{MB}, \mathrm{YE}$ and $\mathrm{RB}$ molecules onto CNAC surface was described by Freundlich model as suggested by regresion analysis. The Dubinin-Radushkevich isotherm indicated a chemisorption process involved in the $\mathrm{MB}$ and $\mathrm{RB}$ removal process. These results were confirmed by pseudo-second-order reaction model and Elovich kinetics model. Elovich model suggested that the exchange of electrons between adsorbent and adsorbate takes place also for EY removal but pseudo-second-order kinetic model did not confirm this result. The low correlation coefficients values obtained from Bangham and Dumwald-Wagner kinetics models confirmed that intraparticle diffusion was not the only rate-controlling step. Further studies are therefore necessary to determine the rate controlling step for $\mathrm{MB}, \mathrm{YE}$ and $\mathrm{RB}$ removal onto CNAC surface. The effect of dyes on chickpea, mustard and corn seeds through seed GI was carried out. The results showed that the percentage of seed germination decreased as the dyes concentration increased, affecting their germination and growth.

\section{Acknowledgements}

The work has been funded by the Competitiveness Operational Programme of the Ministry of European Funds through the Contract No. 7/01.09.2016 and was supported in part by Sectorial Operational Program 
"Increase of Economic Competitiveness" Priority Axis II, Project Number 1887, INOVA-OPTIMA, code SMISCSNR 49164, by PN18-28 0201 and 19PFE/17.10.2018.

\section{References}

1. D. L. Postai, C. A. Demarchi, F. Zanatta, D. C. Cipriani Melo, C. A. Rodrigues Alexandria Engineering Journal, 2016, 55, 1713-1723. DOI:10.1016/j.aej.2016.03.017

2. A. Ebrahimian Pirbazari, E. Saberikhah, M. Badrouh, M. S. Emami, Water Resources and Industry 2014, 6, 64-80 DOI:10.1016/j.wri.2014.07.003

3. M. S. Thabet, A. M. Ismaiel, JEAS, 2016, 6, 70-90. DOI:10.4236/jeas.2016.63007

4. D. Pathania, S. Sharma, P. Singh, Arab. J. Chem., 2017, 10, S1445-S1451. DOI:10.1016/j.arabjc.2013.04.021

5. R. Ansari, Z. Mosayebzadeh, Iran. Polym. J., 2010, 19(7), 541551.

6. K. Shen, M. A. Gondal, J. Saudi. Chem. Soc. 2017, 21, S120S127. DOI:10.1016/j.jscs.2013.11.005

7. U. Jadhav Umesh., N. Dhawale Rhushikesh., V. Dawkar Vishal., D. Chougale Ashok, V. Padul Manohar, TBR 2016, 5(2), 1-6.

8. A. M. Aljeboree, A. N. Alshirifi, A. F. Alkaim, Arab. J. Chem. 2017, 10, S3381-S3393. DOI:10.1016/j.arabjc.2014.01.020

9. M. T. Yagub, T. K. Sen, M. Ang., Environ. Earth. Sci. 2014, 71(4), 1507-1519. DOI:10.1007/s12665-013-2555-0

10. M. R. R. Kooh, M. K. Dahri, L. B. L. Lim, O. A. Malik, Environ. Earth. Sci. 2016, 75, 783.

11. S. Hajati, M. Ghaedi, H. Mazaheri, Desalin. Water Treat. 2016, 57(7), 3179-3193. DOI:10.1080/19443994.2014.981217

12. K. S. Hameed, P. Muthirulan, M. M. Sundaram, Arab. J. Chem., 2017, 10, S2225-S2233.

DOI:10.1016/j.arabjc.2013.07.058

13. M. Rafi, B. Samiey, C.-H. Chen, Materials, 2018, 11(4), 1-24. DOI:10.3390/ma11040496

14. A. Moldovan, E. Neag, V. Babalau-Fuss, O. Cadar, V. Micle, C. Roman, Anal. Lett. 2019, 52(1), 150-162.

DOI:10.1080/00032719.2017.1418879

15. Y.-Y. Lau, Y.-S. Wong, T.-T. Teng, N. Morad, M. Rafatullaha, S.-A. Ong RSC Adv. 2015, 5, 34206.

DOI:10.1039/C5RA01346A
16. B. Mudyawabikwa, H. H. Mungondori, L. Tichagwa, D. M. Katwire, Water. Sci. Technol. 2017, 75(10), 2390-2402.

DOI:10.2166/wst.2017.041

17. I. Langmuir, J. Am. Chem. Soc. 1916, 38, 2221-2295. DOI:10.1021/ja02268a002

18. M. Ghaedi, Sh. Heidarpour, S. N. Kokhdan, R. Sahraie, A. Daneshfar, B. Brazesh, Powder Technol. 2012, 228, 18-25.

DOI:10.1016/j.powtec.2012.04.030

19. F. Kallel, F. Chaari, F. Bouaziz, F. Bettaieb, R. Ghorbel, S. Ellouz Chaabouni J. Mol. Liq. 2016, 219, 279-288.

DOI:10.1016/j.molliq.2016.03.024

20. N. Ayawei, A. N. Ebelegi, D. Wankasi, J. Chem. 2017, Article ID 3039817 DOI:10.1155/2017/3039817

21. H. M. F Freundlich, J. Phys. Chem. 1906, 57, 385-471.

22. F. Deniz, R. A. Kepekci, Int. J. Phytoremediat. 2016, 19(6), 579-586. DOI:10.1080/15226514.2016.1267707

23. M. M. Dubinin, L. V. Radushkevich, Proc. Acad. Sci. Phys. Chem. Sect. USSR 1947, 55, 331-333.

24. F. Deniz, Scientific World. J. 2014, Article ID 138986, 1-10. DOI:10.1155/2014/138986

25. S. Lagergren, Kungliga Svenska Vetenskapsakademiens. Handlingar, Band, 1898, 24(4):1-39.

26. Y. S. Ho, G. McKay, Water. Res. 2000, 34, 735-742. DOI:10.1016/S0043-1354(99)00232-8

27. W. J. Jr. Weber, R. R. Rummer, Water Resour. Res. 1965, 1(3), 361-365. DOI:10.1029/WR001i003p00361

28. H. Qiu, L. Lv, B.-C. Pan, Q.-J. Zhang, W.-M. Zhang, Q.-X. Zhang, J. Zhejiang Univ. Sci. A, 2009, 10(5), 716-724. DOI:10.1631/jzus.A0820524

29. S. Banerjee; M. C. Chattopadhyaya; Uma; Y. C. Sharma, Journal Of Hazardous, Toxic, And Radioactive Waste 2014, 18, 56-63. DOI:10.1061/(ASCE)HZ.2153-5515.0000191

30. K. S. Bharathi, S. T. Ramesh, Appl. Water. Sci., 2013, 3, 773790. DOI:10.1007/s13201-013-0117-y

31. X.-Y. Huang, J.-P. Bin, H.-T. Bu, G.-B. Jiang, M.-H. Zeng, Carbohydr. Polym. 2011, 84 1350-1356.

DOI:10.1016/j.carbpol.2011.01.033

32. J. Y. Farah, N. Sh. El-Gendy, L. A. Farahat, J. Hazard. Mater. 2007, 148, 402-408.

DOI:10.1016/j.jhazmat.2007.02.053

33. E. Rápó, R. Szép, Á. Keresztesi, M. Suciu, S. Tonk, Acta Chim. Slov. 2018, 65, 709-717.

DOI:10.17344/acsi.2018.4401 


\section{Povzetek}

Preučevali smo sposobnost tržnega naravno aktiviranega rastlinskega oglja (ang. kratica CNAC) za odstranjevanje različnih barvil kot so metilensko modro (MB), eosin rumeno (EY) in rodamin B (RB). Na različnih rastlinah smo preko indeksa kaljenja (GI) določili toksičnost barvila, tako da smo merili število vzklitih semen in dolžino korenin. V splošnem se je izkazalo, da visoke koncentracije barvila zavirajo kaljenje, povzročijo spremembo barve in vplivajo na rast. RB pa je imel pri vseh določanih koncentracijah le minimalen vpliv na kaljenje koruznih semen. Adsorpcijo barvil na CNAC smo preučevali preko adsorpcijskih izoterm in modeliranja kinetike. Ugodno adsorpcijo sta pokazala tako Langmuirjev kot tudi Freundlich-ov model. Kinetične študije so pokazale, da lahko hitrost adsorpcije MB in RB opišemo s kinetiko pseudo-drugega-reda, ne pa tudi hitrost adsorpcije EY. 